‘And so it is licly to men': Probabilism and Hermeneutics in Wycliffite Discourse

\author{
Kantik Ghosh \\ Associate Professor of English \\ Stirling-Boyd Fellow and Tutor \\ Trinity College \\ University of Oxford
}

kantik.ghosh@trinity.ox.ac.uk

\title{
Acknowledgements:
}

I am much indebted to Luigi Campi, Ann Giletti, Christophe Grellard, Anne Hudson, Maarten Hoenen, Andrew Kraebel, Ian Levy and Ian Maclean for their comments on earlier drafts of this article, as well as to the anonymous readers for RES. 
Abstract: The Latin sermons of John Wyclif (d. 1384), as also the long English cycle of 294 sermons by his followers drawing on his Latin work, show a pervasive, and surprising, use of the labile and contentious medieval discourses related to probable reasoning. This article attempts to examine the implications of such usage in the context of biblical exegesis, polemics and homiletic exhortation. The Wycliffites, like their master, posited as foundational that access to the divine mind via the Bible, independent of the corruptions and concupiscence of a schismatic Church and a vainglorious theological magisterium, was possible and indeed necessary. However, the evidence of these sermons points in a very different direction, and suggests that a deep hermeneutic and epistemological uncertainty, bordering on what is at times a barely-averted scepticism, underlay their valiant efforts to apply God's word to human affairs.

\section{'And so it is licly to men': Probabilism and Hermeneutics in Wycliffite Discourse}

Commenting on the objections that his opponents might raise vis-à-vis an anti-papalist exposition of Matthew 24, the vigorously polemical Lollard author of Of Mynystris in pe Chirche singles out one of them in particular: why, the opponent is imagined to ask, should one go against the belief of the majority of the Church?

Also pe more part of pe chirche, bope lerude men and lewyde, wolen assente to pis sentence; who schulde panne denye it [?]

(Also, the greater part of the Church, both the learned as well as the ignorant, will agree with this statement; who, then, should deny it?)

Our author reserves some memorably bleak derision for such an argument:

And sipen per ben fewe wyse men, and foolus ben wipowte nowmbre, assent of more part of men makip euydence pat yt were foly.

(And since there are few wise men, while fools are numberless, the assent of the greater part of men provides evidence that it is folly.) 
He further elaborates on the fundamental error in this way of thinking:

for monnys schrewyde customys and false mennys opynyonus preue not per entent but tellon more errour, as zif Yndes or Saraceyns, Grekis or Iewis, han pis opynyoun, it is not perfore sop. ${ }^{1}$

(for the wicked customs of men and the opinions of false men do not prove what they intend but instead indicate even more error: just as, if Indians or Saracens, Greeks or Jews, hold a particular opinion, this does not make it true.)

However, despite this apparently robust dismissal of consensus as an indicator of truth, this tract, and Wycliffite writings more generally, also habitually suggest that a conviction of the truth of a proposition or of an interpretation, if shared by sufficient numbers of (the 'right' kind of) people, may be held to point to the increased 'probability' of the truth of such a proposition. The hermeneutic and epistemological discourses of Wycliffism thereby participate in a complex and contentious body of medieval thought which attempted to parse the role of probability and uncertainty in the realms of moral theology and casuistry, jurisprudence, and ecclesiastical politics; and a wide range of related vocabulary is pervasively deployed in Wycliffite polemical, exegetical and homiletic writings which seek to debate God's Word and apply it to human affairs. This article will elucidate some of the nodal points of this debate with primary reference to the late sermons of Wyclif, and to those of his academic followers writing in English, and attempt to sketch some of the larger intellectual and cultural consequences of this debate in later medieval England.

The discourses of medieval probabilism were vast, contentious and vague. ${ }^{2}$ Probabilis encompassed meanings ranging from 'approved' (as in magistri probabiles) via 'capable of being proved and therefore generating weak assent' (as in scientia probabilis), to the conjectural or the merely plausible, and could at times even be associated with the specious and 'sophistic'. ${ }^{3}$ As Rudolf Schüssler points out: 
Medieval and Renaissance philosophers used probability-related vocabulary; but they did not analyze the underlying concepts in depth [...]. Probability-related terms were usually introduced in passing, and the most differentiated treatments extended to a folio page at best. Nevertheless, issues of probability were not peripheral to medieval thought $[\ldots]$. [Medieval thinkers were] highly aware that many claims in jurisprudence, theology and medicine could not be derived with certainty from indubitable premises. Hence, arguments in these fields had to rely more often than not on probable reasoning [...]. The normative and regulatory uses of probability were anchored in scholastic theology and jurisprudence. ${ }^{4}$

An important aspect of probabilistic thought had to do with assent, and two key definitions of the concept, those of Cicero and Boethius, were central to its medieval understanding. Cicero defined the 'probable' as that which 'for the most part usually comes to pass, or which is a part of the ordinary beliefs of mankind, or which contains in itself some resemblance to these qualities, whether such resemblance is true or false'. Boethius held that something is 'probable' 'if it seems true to everyone or to most people or to the wise - and of the wise, either to all of them or most of them or to the most famous and distinguished - or to an expert in his own field [...]'. He is drawing here on the fundamental Aristotelian concept of endoxon: opinions 'which are accepted by everyone or by the majority or by the wise - i.e., by all, or by the majority, or by the most notable and reputable of them'. ${ }^{5}$ As will be evident from these foundational formulations, there is inbuilt into the concept and discourses of probabilism a basic ambiguity: is something more 'probable' because it is more likely to be 'true', or is something more 'probable' because it is more easily or habitually perceived as 'true'? ${ }^{6}$ The first question points towards to the realm of truth (i.e. epistemology); the second, problematically, to persuasion (i.e. rhetoric) ${ }^{7}$ and both epistemological and rhetorical claims are of course central to biblical hermeneutics. Equally important to the 
above definitions is the role of the community, of 'experts', of 'the wise' and so on; in other words, the question of legitimate authority, and of its identification and location, whether in an individual, a group, or an institution, is at the heart of 'probable' discourses. ${ }^{8}$ However, the Wycliffite tract discussed above is clear that endoxon is entirely inadequate as a hermeneutic criterion: it dismisses the authority of experts (the 'lerude men'), as also the validity of 'custom' or 'opinion'.

Wyclif himself uses probabilistic vocabulary extensively in his late sermons, which were in large part composed, compiled and edited in the final years of his life when he had been forced to retire from Oxford to his parish in Lutterworth. ${ }^{9}$ The most salient and frequently used words and phrases include: probabilis and its variants; communiter dicitur / intelligitur / dubitatur ('commonly said / understood to be', 'commonly questioned / investigated'); and the various forms of the word musare, 'to muse / wonder / doubt'. Wyclif's usage of these words and phrases in his biblical exegesis is, in keeping with wider medieval practice, mobile and diverse, and it is instructive to look at some specific instances.

A first category of (relatively uncontentious) usage relates to the defence of a particular reading of a scriptural passage in the context of homiletic exhortation. Commenting on the Baptist's words (John 1:27), ${ }^{10}$ Wyclif reprises the fractious medieval debate over whether or not Christ walked barefoot. Dismissing the debate as fatuous by sensibly asserting that there are more important aspects of Christ's ministry - such as his rejection of all avarice for temporal goods - which ought to demand our attention, ${ }^{11}$ Wyclif nevertheless cannot resist giving his implicit endorsement to a particular figurative interpretation: 'Et sic intelligunt quidam probabiliter Baptistam intelligere se non esse dignum ligamentum religionis huius Christi dissolvere' ('And thus some understand the Baptist to have probably meant that he was not worthy to break or dissolve the bond of this religion of Christ'). ${ }^{12}$ Again, commenting on Luke 11:29, ${ }^{13}$ which Christ applied to the Jews, Wyclif says: 'Et a 
probabili est de christianis conformiter senciendum' ('And probably [this statement of Christ's] is to be conformably believed of Christians'). Indeed, Wyclif goes on to comment: 'Et cum diabolus ac membra sua procedunt in deterius augmentando, probabile videtur quod ista christianorum generacio est peior quam predicta generacio Judeorum' ('And since the devil and his members proceed in making things ever worse, it seems probable that this generation of Christians is worse than the aforementioned generation of Jews'). ${ }^{14}$ It is worth recalling here that such a context of homiletic moral exhortation was regarded as especially hospitable to probable arguments and persuasions; indeed, a number of later medieval thinkers parsed in detail the epistemic and rhetorical principles appropriate to what they described as 'moral logic'. 15

Also relatively familiar and uncontentious is the category of the 'probable' which relates to inferences based on the scriptural narrative but for which explicit factual biblical evidence is not available. ${ }^{16}$ For example, it is greatly probable that the marriage at Cana was that of St John the Evangelist (to a woman unknown to us); ${ }^{17}$ or again, that the Magi looked for the prophesied baby Jesus in the royal city of Jerusalem when they arrived there guided by the star: 'in civitate regia regem prophetatum probabiliter quesierunt'. ${ }^{18}$ And the star itself, given that it was visible in the daytime, was probably newly created near the earth and not one of the ones extant from the creation of the universe: 'sancti probabiliter convincunt quod hec stella non fuit celestis in principio mundi facta, sed noviter creata, in infimo aeris intersticio miraculose mota, quia luxit in die et per consequens sensibilior stellis celestibus fuit prope' ('The saints show in a probable manner that this star was not created as celestial at the beginning of the universe, but [was instead] newly created, [and] miraculously moved to the lowest zone of the air, since it shone during the day and, as a result, was more readily perceptible [by the senses] than the celestial stars'). ${ }^{19}$ 
However, probabilistic vocabulary is also deployed in more speculative contexts, as for instance when Wyclif, basing himself on Genesis 1, embarks on a complex and idiosyncratic philosophical exploration of creation, prime matter and time. ${ }^{20}$ Interpreting the scriptural reference to God's 'rest' on the seventh day (Genesis 2:2-3) as a cessation from creating new orders of beings, Wyclif says of his entire reading of the account of creation (which he posits is truly Augustinian): ${ }^{21}$ 'Ista autem videtur via probabilis et consona fidei scripture, cum omnes emuli Augustini nesciunt viam faciliorem, magis probabilem, vel scripture plus consonam sompniare' ('For this seems to be a probable way [of understanding the Genesis narrative] and in consonance with the faith of Scripture, since all those who would seek to outdo Augustine do not know how to dream up an easier, more probable way [i.e. one which is more susceptible to being proved] or one which is more in consonance with scripture.' $)^{22}$ In a similar vein, the discussion of the feeding of the multitude by means of seven loaves of bread (Mark 8) leads into a compressed and allusive account, also drawing on Wyclif's theory of prime matter, of the various philosophical explanations of how this miracle may have been possible, followed by an assertion that one of the proposed explanations is probable. ${ }^{23}$

Invocations of the 'probable' are also resorted to in more explicitly polemical contexts. In a dubium on the subject of the supposed priestly ability to absolve the sinful, a probable opinion (one which is held to be in consonance with both reason and the faith of scripture) is vouchsafed against such priestly authority: '[Sed dubitatur] si quilibet sacerdos posset absolvere a quocunque crimine vel ad quantum. Et currunt testimonia sanctorum pro utraque parte. Ideo superest quid secundum fidem scripture et racionem probabiliter posset dici, et videtur quod nemo citra Christum potest simpliciter absolvere a peccato' ('But it is questioned whether any priest would be able to absolve of any sin or crime, and [if so], to what extent. The testimony of saints is available [in support of] either side of the question. 
Therefore the superior answer is the one which may probably be said to be according to the faith of scripture and reason, and it seems no one lesser than Christ can absolve from sin absolutely'). ${ }^{24}$ On a similar subject, it is held that there is no need to heed clergy who assert that withholding tithes offends Christ, as it is unlikely - i.e. unsupported by probable evidence from their modus vivendi - that they belong to the predestined, i.e. are members of the true Church: ${ }^{25}$ 'Sed cum nec habent inspiracionem nec evidenciam ex vita sua probabilem quod sunt predestinati vel salvandi et per consequens membra Christi, patet quod inverecunde secundum scolam dyaboli menciuntur' ('But since they neither have inspiration [from the Holy Spirit] nor any probable evidence from their life that they are predestined or saved and therefore a member of Christ, it appears that they lie shamelessly according to the school of the devil'). ${ }^{26}$

Wyclif's characteristic deployment of probabilistic vocabulary is often accompanied by an implicit invocation of a 'common sense or understanding' ${ }^{27}$ We should recall here that, in medieval jurisprudence, 'attitudes towards the moral authority of the majority and the status of the probable' were closely related: 'Legal commentators in both the canonistic and civilian traditions accepted that the common opinion of the doctors (communis opinio doctorum) provided a probable (and hence reliable) judgment on disputed matters'. ${ }^{28}$ In the context of fourteenth-century theological debate, Andrea Aldo Robiglio has pointed out that 'ecclesiastical authorities tried to give a coherent picture of Christian doctrine, in an effort to cope with an increasing state of "crisis" and changes in practices and beliefs. [...] In this context, the notion of common doctrine [doctrina communis] became a strategic tool: it was the guarantor of truth, insofar this was understood as "orthodoxy" in opposition to an increasing number of "heresies"”. ${ }^{29}$ However, in Wyclif's sermons, it is never clarified in theoretical terms where such a 'common' understanding is to be located, and why it should be of any exegetical value. ${ }^{30}$ Commenting on Matthew $8: 2,{ }^{31}$ Wyclif refers in passing to an 
interpretation of leprosy as pride: 'Et confessio talis est disposicio necessaria in superbis qui intelliguntur communiter in leprosis' ('And such a confession [of faith] is a necessary disposition in the proud who are commonly understood by the lepers'). ${ }^{32}$ Dicitur communiter is a recurrent phrase, apparently suggesting an endorsement of a particular exegetical or doctrinal point; I Corinthians $4: 7,{ }^{33}$ for instance, is held to point to the worst kind of pride: 'Unde dicitur communiter quod superbia talis contra legem Dei, contra legem nature et contra legem humane iusticie' ('Whence it is commonly said that such pride [is] against the law of God, the law of nature and the law of human justice'). ${ }^{34}$ Or again, far more speculatively, a trio of possible reasons is vouchsafed for the Magi seeking the Christ child in Jerusalem in the absence of the miraculous guiding star: 'Unde dicitur communiter quod triplex est racio quare disparente stella in Jerusalem dominum quesierunt' ('Whence it is commonly said that there are three reasons why, in the absence of the star, [the Magi] looked for the Lord in Jerusalem'). ${ }^{35}$ Occasionally, Wyclif does clarify that the consensus-understanding that he is proposing is supported by the scholarly community: an account of the variously laudable grades of chastity (conjugal, widowed and virginal) is prefaced by an assertion that such is the 'common opinion' of doctores: 'dicunt doctores communiter' ${ }^{36}$ It must also be to a scholarly consensus, or to a scholarly convention of speaking, that Wyclif refers when he asserts, in the context of a discussion of creation and what Genesis $1: 2^{37}$ signifies, that 'dicitur communiter quod virtus cognitiva fertur super obiectum quod concipit' ('it is commonly said that the cognitive faculty or power is borne over the object that it conceives'). ${ }^{38}$ 'Common doubts or questions' are also occasionally referred to. In the context of a compressed logical-philosophical analysis, based on various understandings of predication, of how it is that Christ may be held to be united with his members, 'communiter dubitatur' must refer to common academic questioning, given the technical philosophical underpinnings of the discussion. ${ }^{39}$ On another occasion, though, the "common doubt or 
question' invoked is fairly rudimentary and could presumably be shared by anybody: Matthew 9:1 refers to Jesus entering into his own town, 'civitatem suam', without it being specified which town, whether Jerusalem or Nazareth or some other place, thereby leaving it an open matter. ${ }^{40}$

Occupying an adjacent semantic field in Wyclif's sermons is the verb musare, which has the rough sense of 'question' / 'wonder about (in a negative sense)' / 'raise difficulties'. ${ }^{41}$ Jesus' obscure words in John 16:16 ${ }^{42}$ plunge his disciples into confusion (John 16:17-18): 'ignorantes hanc Christi sentenciam' ('not knowing [the meaning of] this utterance of Christ'), the disciples 'de suis sermonibus mussitarunt' ('muse on his words'). ${ }^{43}$ Again, Mark 16 gives occasion for 'common musing' on the identity and number of Maries: 'Circa hunc textum communiter musitatur utrum erant tres Marie [...] vel tantum due' ('In relation to this text it is commonly "mused" whether there were three Maries [...] or only two'). ${ }^{44}$ 'Musing' is closely linked to the realm of the probable (even if uncertain); Jesus fasts no more than forty days in the desert in order to moderate the devil's 'musing' so that he would not by 'probable conjecture' come to the conclusion that Jesus was indeed the Messiah:

Jeiunavit autem solum quadriginta diebus sed sine cibo et potu simpliciter [...] quia per hoc Deus mussitacionem diaboli moderavit, ut propter excessum sui ieiunii supra Moysen et Helyam non ipsum esse Messyam, Deum et hominem probabili coniectura convinceret. $^{45}$

Though he fasted only for forty days, he did so without any food and drink [...] because by doing so God tempered the Devil's "musing", so that via his excessive fast beyond [that undertaken by] Moses and Elijah [i.e. one in which he would suffer acute hunger as these others did not], he would not demonstrate himself to be the Messiah, both God and man, by probable conjecture. 
'Musing' in the sense of '(possibly) pointless speculation' can also be opposed to 'probable suspicion, ${ }^{46}$ which has to do with contingent but nevertheless largely reliable views arising out of cognitive approaches which allow an approximation of the truth relative to our abilities. $^{47}$ 'Musing' can also be opposed to a correct acceptance of the axiomatic. Just as it is natural for philosophers to set out from an acknowledgement of first principles and axioms without asking for evidence in support of these, similarly do the faithful believe in their faith without 'musing' on supporting evidence: 'Sicut ergo naturale est philosophum principia sua cognoscere sine evidencia precedente, sic naturale est fidelem fidem suam credere sine musitacione evidencie precedentis'. ${ }^{48}$ Indeed, 'musing' can at times be dismissed as akin to grumbling about or finding fault with the divine ordering of things: the ungrateful infidels 'qui diabolice non contentantur de Dei munificencia [...] murmurant vel musitant quare [Deus] non fecit melius' ('who, in a reprehensible way, are not satisfied with the munificence of God [...] [instead] grumble and "muse" about why God did not do better'). ${ }^{49}$ Wyclif's diffuse usage of probabilistic vocabulary in his sermons remains a conundrum. As I have pointed out elsewhere, the question arises 'as to how this probabilistic vocabulary fits in with Wyclif's otherwise foundational emphasis on the close isomorphism of language, thought and world as grounded in divine ideas' ${ }^{50}$ Recent commentators, most notably Alessandro Conti, Laurent Cesalli, Alexander Brungs and Frédéric Goubier, have illuminated what they consider Wyclif's innovative theories of language, scripture and truth, arising out of his often idiosyncratically realist Sprachlogik, much of which, in addition to attracting a devoted following, elicited bemusement and criticism from his contemporaries. ${ }^{51}$ Wyclif's hermeneutic practice, however, is closer to bricolage: it relies on and appears to draw at will, and seemingly without any necessary rigour, on the wide range of late-scholastic methods and vocabularies at his disposal, many of them notably inflected by probabilistic and sceptical impulses. ${ }^{52}$ Indeed, the most recent student of his Postilla super totam bibliam, 
Andrew Kraebel, characterises its scriptural lectio as one informed by an 'eclectic hermeneutics'. ${ }^{53}$ The sermons too suggest that the practical moral-exegetical needs of the homiletic mode, and the local polemical advantages offered by the discourses of probabilism - as for instance when attacking the Church's dogmatic and institutional claims - overrode any sense of the disjunction that Wyclif may have had of such discourses from his global theories of scriptural signification and of the isomorphism of language and reality.

This disjunction - between a foundational assertion of the absolute truth of scriptural language and form and the implications of such a pervasive use of probabilistic discourses when attempting to interpret and use that language in homiletics and polemics - had a significant afterlife in English. Wyclif's Latin sermons were quarried by his academic followers (presumably based at Oxford) when they came to compose a long cycle of 294 sermons in the vernacular, extant in many manuscripts and widely disseminated, and edited by Anne Hudson and Pamela Gradon as The English Wycliffite Sermons. ${ }^{54}$ The English writers drew extensively though loosely and imprecisely on Wyclif's Latin sermons and other writings. ${ }^{55}$ Unsurprisingly therefore, the vocabulary related to probabilism that we have been examining is to be found pervasively in the English sermons; if anything, the frequency and diversity of usage increase. ${ }^{56}$ The Latin impersonal phrasing of probabiliter / communiter dicitur is generally rendered in English via the use of the indefinite (and inclusive) 'men'. 57 Typical formulations include: 'men seyn / tellen / spekon comunly' ('men say / tell / speak commonly'); 'men supposon' ('men suppose'); '59 'men dowton comunly' ('men question or doubt commonly'); ${ }^{60}$ 'pus it semep to monye men' ('thus it seems to many men'); ${ }^{61}$ 'monye men penkon' ('many men think'), ${ }^{62}$ 'men may muse / muse we not' ${ }^{63}$ Less frequently occur 'somme men construen' ('some men construe or interpret'); 'men vndurstonde' ('men understand'); 'men han proued ofte-tymus' ('men have proved or experienced often'); 'somme men trowe' ('some men believe'); 'it were more licly to men' ('it would seem more 
likely to men'); 'it is knowon ping ynow' ('it is an acknowledged thing') and variations on these. ${ }^{64}$ This standard phrasing with an unspecified community of 'men' as subject is to be noted. It foregrounds, more than is the case with Latin, the question of interpretative and ethical agency; furthermore, by using 'men' instead of 'clerks', the Aristotelian-Boethian emphasis on endoxon, on the opinion of experti or periti, is sidelined in favour of a more diffuse and less hierarchical or institutionally specific location of interpretative authority. ${ }^{65}$ Sermon 39 in the Proper of Saints, in part drawing on Wyclif's sermon on the same theme, is particularly notable for its use of this vocabulary. Its theme is set by Matthew 2:1316 (the slaughter of the innocents). Following Wyclif (who prefaces his discussion with a 'ut probabiliter opinatur'), ${ }^{66}$ the sermon holds that Herod, 'as men seyen comunly', went to Rome immediately after the birth of Christ and stayed there for two years; hence his order on return to kill all children up to the age of two. ${ }^{67}$ Matthew 2:17-18 then cites Jeremiah 31:15 (Rachel weeping for her children), ${ }^{68}$ and the vernacular exegesis, drawing on Augustine and Wyclif, ${ }^{69}$ suggests that Rachel was weeping because her children, unlike those of her sister Leah, were not martyred for Christ and were therefore not predestinate. Differing exegeses of the significance of Rachel and her tears are then offered: 'somme men vndurstonden', 'opre men vndurstonden', 'we trowen pat' ('some men understand', 'other men understand', 'we believe that'). ${ }^{70}$ Wyclif's own sermon on the theme offers a dubium: ${ }^{71}$ 'Sed circa hoc evangelium dubitatur si dicti occisi singuli sunt beati, cum a probabili multi eorum sunt occisi ante diem octavum' ('But it is questioned in relation to this gospel passage if each of the slaughtered [innocents] was blessed, since it is probable that many of them were killed before the eighth day [i.e. before being circumcised]'), and he frames his extended discussion of the subject primarily in terms of 'probable opinion' as opposed to 'presumptuous definition'. ${ }^{72}$ The English sermon radically compresses Wyclif's dubium but retains a great part of his probabilistic vocabulary: 'But men douton comunly hou alle pese weron martiris' ('But men 
doubt or question commonly whether all these [innocents] were martyrs'); 'But licly monye of hem weren kyllud byfore pe eystbe day' ('But it is likely that many of them were killed before the eighth day'); 'here monye men penkon'; 'as it is knowen comunly'; 'so may men suppose' and so on. The entire discussion is then concluded with: 'And so alle pes innocentus weron circumcisid in soule. Pus men may suppose bynepe byleue' ('And so all these innocents were circumcised in soul. Thus men may suppose in a way that is inferior to belief') ${ }^{73}$

The English sermon - as also Wyclif - is here drawing on a technical scholastic vocabulary pertaining to the different grades of assent, from 'belief' to 'supposition' to 'doubt', ${ }^{74}$ and this interest in epistemic categories informs the polemical critique of the Church's canonisations which forms the sermon's extended coda. The sermon makes the standard Wycliffite point that it is only of those saints who are "expressud in pe lawe of holy writ' ('explicitly referred to in the law of holy scripture') that it is required that men 'trowe expressely pat pese ben seyntus in heuene' ('believe explicitly that these are saints in heaven'). Any other kind of 'supposition' regarding other (putative) saints is held to be of lesser probability than that pertaining to the salvation of the slaughtered innocents: 'And monye men supposon pis more pan of pes seyntus pat now ben canonysede by pe court of Rome, for lordschipe, or money, or fauour of partus' ('And many men suppose this [that the innocents were saved] more than they do so of these saints who have now been canonised by the [papal] court of Rome, either for power, or money, or favouritism towards individuals'). Then, in notably convoluted syntax pointing, I think, to the homilist's uneasy awareness that this attempt to set up a hierarchy of 'suppositions' is on very shaky ground indeed, the sermon points out that some men are so foolish as to 'suppose benepe byleue pat opre men ben seyntus, aftur euydence pat pei han, opur more or lesse, as somme men supposon' ('suppose in a way that is inferior to belief that [some] other men are saints, according to the 
evidence that they have, whether greater or lesser, as some men suppose'). The sermon then returns to the theme of the different grades of truth offered by holy writ (and therefore the different kinds of assent required by such 'truths'): it contains some 'truths' expressly and these demand 'express' faith in them; other 'truths' it contains 'pryuely, and pat schulde men trowen in comun' ('in a hidden way [i.e. in an oblique, parabolic or figurative, occult or mystical fashion], and these men should believe in common'), without seeking to arrive at definitive judgements. The implication here is that 'common belief', i.e. a generally shared consensus as to which implicit meanings a scriptural passage may be held to endorse, is at best an indication of probability, and in any case to be ranked lower in epistemic terms than the 'express' statements of scripture, i.e. explicit propositions which are held to be independent of human interpretation. ${ }^{75}$ The sermon clarifies that the realm of probable truths does not admit of 'definition', i.e. certain judgement: 'men schulde not here diffyne' even if a particular view 'were more licly to men'. A convoluted discussion is embarked on as to whether or not Thomas Becket was indeed a saint, or where in the heavenly hierarchy he may be placed - the sermon suggests that we cannot know either way, ${ }^{76}$ even if fools, such as those in the fraternal orders, will fight over the respective positions of their patrons in the celestial hierarchy and other such delusions: 'But men may trowe, whoso wole, pes fables for whiche foolus stryuen' ('But men may believe, whoever so wishes, these fables over which fools fight'). However, the apparent resignation to the inevitable uncertainty of our probable opinions ('lesse pan feip'), with derision reserved for those who foolishly fight over the unknowable, emerges in all its unease right at the end of the sermon: 'But al oure craft were for to knowe what we schulden take as byleue, and what ping we schulden suppose, and what ping forsake as false' ('But all our strength and skill ${ }^{77}$ should be devoted to knowing or ascertaining what we should accept as belief, and what we should [merely] suppose [to be true], and what we should forsake as false'). ${ }^{78}$ Therein lies the rub, we might well add. 
I have examined the foregoing passage at some length in order to bring out the fundamental tension between the sermons' pervasive invocation of the vocabulary of supposition, uncertainty and probabilism and their theoretical investment in a moral and doctrinal certainty which can bypass or override, via direct engagement with Holy Scripture, the structures and frameworks of authorised knowledge, including the ecclesiastical hierarchy and the 'tradition' it upholds, and the university and its theological magisterium. This emerges most clearly in polemical contexts. In a tirade against the 'new orders' of the friars in Sermon 66 of the Proper of Saints, the homilist simultaneously deploys probabilistic language and the language of certainty. The body of holy church has been 'ordeyned of Crist by euery part and iuncture perof' ('ordained or authorised by Christ in its every part and joint'), and therefore 'it semep to monye men' that these new additions, in the form of the new religions, are as rotten 'postims' ('pustules'?) on that body. And 'pus penkon monye men' that these orders should be suspect until they have been able to 'ground' themselves adequately in Christ's law. Indeed, 'men supposon as heresyes' all such novelties not based in God's word. The probabilistic approach reflected in the use of the verbs seem, think and suppose is however upended almost immediately via an invocation of 'conscience': all these unwarranted accretions 'semon by lawe of conscience to be azenys Godus wille' ('seem by law of conscience to be against God's will'). ${ }^{79}$ The almost paradoxical verbal clauses - 'it seems by the law of conscience'; 'men suppose to be heresies' (emphases mine $)^{80}$ - neatly encapsulate the basic décalage of the discourses of probabilism and certainty. As another sermon says: 'Leue we here pes tryuaunt douztis and enforse vs to lerne Cristis wordis' ('Let us reject here these foolish doubts and questions, and instead strive to learn / understand Christ's words'), ${ }^{81}$ again a quasi-paradoxical formulation, since a fundamental hermeneutic recognition of the sermons is the vast penumbra of doubtful 'supposition' which must 
necessarily surround the core certitudes - and even those are not immune to doubts - offered by an often elliptic and opaque parabolic scriptural discourse.

The - perhaps inevitably - ambiguous positioning of probable discourses informs the polemical tract, Of Mynystris in pe Chirche, with which we started. ${ }^{82}$ The vernacular tract, which in part draws on Wyclif's own exposition of Matthew $24,{ }^{83}$ responds to his protestatio praemissa thus: ${ }^{84}$

Omnia autem hic exposita sunt tanquam dicta probabiliter capienda, protestando quod si aliqua persona ecclesie docuerit sensum magis probabilem, illi volumus humiliter consentire. ${ }^{85}$

(Everything expounded here is, as it were, to be taken as probable statements, and we 'protest' that if some member of the church were to teach a sense that is more 'probable' [i.e. more susceptible to being furnished with proofs], we would consent to him with humility.)

And al zif pei wyton wel pat pis text is of byleue, nerpeles pe expounyng is supposed bynepe byleue, ${ }^{86}$ and pei ben redy to take mekely betur wyt zif it be taw3t hem, and to forsake her owne wyt 3 if any teche pat it is fals. ${ }^{87}$

(And although they well know that this text is worthy of belief, nevertheless the exposition is to be supposed as inferior to belief, and they are ready humbly to accept a better understanding if it were demonstrated to them, and to forsake their own understanding if any should demonstrate that it is false.)

Similar protestations surface throughout the tract drawing attention to the (ostensibly) provisional and probabilistic nature of the interpretations offered: 
This wit vndurstondep Crist by pes wordis as we supposon; and, by oure protestacion byfore, we wolon mekely amende pis, or azeyncalle pis, zef we ben tawte pat it is false.

(This is the meaning that Christ understands or intends by these words as we suppose; and, by our above protestation, we wish humbly to amend or withdraw this [exposition], if it is demonstrated to us that it is false.)

But zet we vndurstonde pus, stonding oure protestacioun [...].

(But yet we understand thus, always assuming our protestation [...].)

Wip pe protestacion seyd byfore vndurstonden men pis tixt pus [...].

(With the protestation made before, men understand this text thus [...].)

But euermore we ben redy to azeyncalle pis gloos whoso prouep pat it is fals or ellis techep a betture. ${ }^{88}$

(But we are always ready to withdraw this exposition or gloss whenever someone proves that it is false or else teaches a better one.)

However, it is not entirely clear how 'good' exegetical speculation such as indicated here is to be distinguished from 'bad' speculation, which is repeatedly dismissed as 'musing'. Muse we not is a recurrent phrase, and particular contempt is reserved for those who will 'muse' on man-made laws when a perfect divinely bestowed eternal law is already available: 'And sip we han pe same lawe pat euermore schal stonde wip us, he is an ouer-greet fool pat musup on newe lawis made of men' ('And since we have the same law that shall remain with us for ever, he is an utter fool who muses on new laws made by man'). ${ }^{89}$ The tract is notably aware of the contentious status of its interpretations, and repeatedly intervenes in theoretical hermeneutic terms into its own exegesis. Aware that it is 'opon heresye' to contradict Christ, the exegetes who expound Christ's law, cautions the tract, must be extremely wary ('men 
schulden be ful war pat expounen Cristus lawe'): 'And so somwhat is seyd here by supposyng or gessyng, and somwhat by byleue and somwhat by qwic resoun.' ('And so some of what is said here has been arrived at by supposition or guesswork, some via belief, and some by means of an alert and active reason'). ${ }^{90}$ When assessing interpretations of holy writ, one must be aware how specious and (rhetorically) beguiling the fiend can be: 'for pe feend wole seyze no ping but zif he haue som colour perto and suppose pat som mon wole byleue pat by pis colour' ('for the devil will not assert anything unless he has some [supporting] rhetorical embellishment or trick, and supposes that some men will believe it because of this trick'). ${ }^{91}$ In fact, the entire edifice of papal law has as one of its main purposes the inculcation of 'perplexity' in men: 'But certis among opre deedis pat pe popis lawe dop to men, it makup hem perplex, and byndup here conscience wip feynede bondis' ('But certainly, amongst other effects that the pope's law has on men, is that it makes them perplexed, and binds their conscience with pretend bonds'). ${ }^{92}$

Indeed, this tract, and cumulatively, the sermons provide evidence of a pervasive awareness of the power of institutions and institutionalised discourses and the (frequently self-interested) hermeneutics they support and promote. They are, at the same time, equally aware of the contingency of their own interpretations, an awareness which results in a sustained effort to theorise their readings in logical, epistemological and hermeneutic terms: almost every gloss is glossed with a piece of meta-commentary. The resultant discursive texture is distinctive and far removed from that of other large-scale contemporary English homiletic productions such as John Mirk's Festial or the macaronic collection of Benedictine provenance in Oxford, Bodleian Library, MS Bodley $649 .{ }^{93}$ It is equally distant from that of the major authorities of biblical exegesis such as the Glossa ordinaria or Nicholas of Lyra: the sermons display an insistent self-awareness and need to qualify, buffer or support their readings at a micro-level going far beyond the large-scale aspirational statements of 
hermeneutic intent in prologues or other prefatory material which tend to accompany biblical commentaries. ${ }^{94}$ All of which ultimately amounts, de facto, to nothing less than the acknowledgement of a 'criterion-problem'. For all their - at least in appearance - finely parsed vocabulary of grades of belief and the criteria which should accompany each grade, a vocabulary which, as we have seen, draws extensively on medieval probabilistic thought, Wycliffite hermeneutic discourses as evidenced in these texts cannot but keep returning to the issue of uncertainty. Certainty is of course the desideratum, given Wycliffism's existential and soteriological investment in a reliable access to divine meaning, enshrined in Holy Scripture, as fundamental to its claim to override the authoritative structures of both the ecclesiastical hierarchy and the scholastic magisterium. Formulated in other words, one might say that certain access to God's mind via his Word is basic to positing a cognitive-textual instead of an hierarchic-institutional concept of faith. ${ }^{95}$ The larger rhetoric of Wycliffism often suggests - indeed, must suggest, given its politics - that such certainty is within reach of the company of 'true men' and lovers of God's law, ${ }^{96}$ but what emerges cumulatively from a significant body of academic Wycliffite writings is a kind of scepticism, closely aligned to the 'perplexity' that the texts lament as one of the determining conditions of postlapsarian humanity estranged from the Word. Indeed, it is notable that this group of Wycliffite writings, to which one might add polemical tracts such as the one on eucharistic philosophy and theology, De oblacione iugis sacrificii, ${ }^{97}$ appears to eschew any sustained or programmatic engagement with the 'ecstatic' or the 'prophetic' as an obvious way to cut the Gordian knot of hermeneutic perplexity, ${ }^{98}$ even though there are elements in Wyclif's own theorisations which might have supported such a move. ${ }^{99}$ The underlying reasons and implications of such a stance demand further investigation, though Wycliffism's conflicted yet foundational relationship to the scholastic theological enterprise may be assumed to play a role. $^{100}$ 
In a penetrating essay on Jean Gerson and his attempt to fashion a workable notion of moral certainty adequate to support decision-making in a 'perplexing' moral and ethical landscape, Rudolf Schüssler locates Gerson's thought in the context of the 'epistemological shock' provided by the Great Western Schism when 'the traditional communitarian and hierarchical modes of intellectual assurance' broke down. ${ }^{101}$ The English Wycliffite texts examined in this article are, in part, responding to the same crisis of authority, ${ }^{102}$ and while theirs is a less nuanced and more muddled attempt, from a very different (extra-)institutional position, it is no less urgent as it seeks to fashion a way out from the morass. However, despite this undoubted urgency, there remains a bracing, almost Langlandian, intransigence about these texts, an inability or unwillingness to leave on one side uncomfortable aperçus; and therefore they end up, in a pervasive doublebind, both disacknowledging and acknowledging the inevitability of uncertainty. 'But no man schulde do owt but ping pat he were certeyn inne; for as it is foly to chese pe worse, so it is foly to cheson vncerteyn' ('But no man should do anything unless he were certain of it, for as it is folly to choose the worse, so is it folly to choose what is uncertain'). ${ }^{103}$ For all their efforts to show us the folly of such a choice, these texts implicitly acknowledge that it is perhaps not, ultimately, given to us to avoid either folly or perplexity, ${ }^{104}$ and that, pace their Master the doctor evangelicus, even God's Word is of limited help when we attempt to do so. 
${ }^{1}$ Of Mynystris in pe Chirche, ed. Pamela Gradon, in English Wycliffite Sermons, eds Anne Hudson and Pamela Gradon, 5 vols (Oxford, 1985-96); 2. 328-65 (350/609-11; 354/713-5; 355/737-40). All subsequent references are to this edition (henceforth EWS), and supplied in the footnotes by volume, page and line number. All translations from Middle English are my own.

${ }^{2}$ I use the word probabilism as a convenient shorthand to designate the discourses surrounding and supporting modes of probable reasoning and argumentation. This is to be distinguished from the specific sixteenth- and seventeenth-century moral-philosophical phenomenon of what is conventionally known as 'scholastic probabilism': on this latter, which does not form the subject of this article, see Rudolf Schüssler, 'On the Anatomy of Probabilism', in Jill Kraye and Risto Saarinen (eds), Moral Philosophy on the Threshold of Modernity (Dordrecht, 2005), 91-113.

${ }^{3}$ For a succinct treatment of the diverse range of meanings attached to the word 'probabilis', see Thomas Deman, 'Probabilis', Revue des sciences philosophiques et théologiques, 22 (1933), 260-90. Other useful studies of this large subject include James Franklin, The Science of Conjecture: Evidence and Probability before Pascal (Baltimore, 2015); Edmund F. Byrne, Probability and Opinion: A Study in the Medieval Presuppositions of Post-Medieval Theories of Probability (The Hague, 1968); Ilkka Kantola, Probability and Moral Uncertainty in Late Medieval and Early Modern Times (Helsinki, 1991); Eileen C. Sweeney, 'New Standards for Certainty: Early Receptions of Aristotle's Posterior Analytics', in Dallas G. Denery II, Kantik Ghosh and Nicolette Zeeman (eds), Uncertain Knowledge: Scepticism, Relativism and Doubt in the Middle Ages (Turnhout, 2014), 37-62. On the role of probable thought in medieval jurisprudence, see Jean-Philippe Lévy, La hiérarchie des preuves dans le droit savant du moyen-âge depuis la renaissance du droit romain jusqu'à la fin du XIV siècle (Paris, 1939), 26-31, 109; for early modern jurisprudence, see Ian Maclean, Interpretation 
and Meaning in the Renaissance: the Case of Law (Cambridge, 1992); on medicine and probabilism, see Ian Maclean, Logic, Signs and Nature in the Renaissance: the Case of Learned Medicine (Cambridge, 2002). A recent, and relevant, treatment of ethics and moral philosophy is by Emily Corran, Lying and Perjury in Medieval Practical Thought: A Study in the History of Casuistry (Oxford, 2018).

4 'Probability in Medieval and Renaissance Philosophy', in The Stanford Encyclopaedia of Philosophy (pubd online 2014) < https://plato.stanford.edu/entries/probability-medievalrenaissance/> accessed 10 July 2018, 2/19; see also Figure 5.1 in Franklin, Science of Conjecture, 119.

${ }^{5}$ Cicero, De inventione, I.29.46; Boethius, De topicis, $1180^{\mathrm{b}} 28$; Aristotle, Topics I, $100^{\mathrm{b}} 20$; cited by Schüssler, 'Probability', 5-6/19. On endoxon and its reception in the Middle Ages, see the following papers by Peter von Moos, "WWas allen oder den meisten oder den

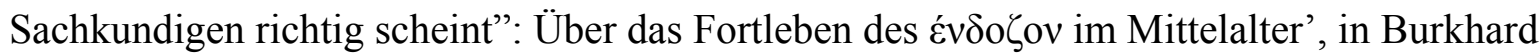
Mojsisch and Olaf Pluta (eds), Historia Philosophiae Medii Aevi, 2 vols (Amsterdam, 1991), 2. 711-44; 'Die angesehene Meinung. Studien zum endoxon im Mittelalter II', in Thomas Schirren and Gert Ueding (eds), Topik und Rhetorik: ein interdisziplinäres Symposium, (Tübingen, 2000), 147-68; 'Die angesehene Meinung. Studien zum endoxon im Mittelalter III: Abaelard', Freiburger Zeitschrift für Theologie und Philosophie, 45 (1998), 343-80; 'Die angesehene Meinung. Studien zum endoxon im Mittelalter IV: Johann von Salisbury', Mittellateinisches Jahrbuch, 34 (1999), 1-55; 'Introduction à une histoire de l'endoxon', in Christian Plantin (ed.), Lieux communs, topoï, stéréotypes, clichés, (Paris, 1994), 3-16; revised version in Peter von Moos, Entre histoire et littérature. Communication et culture au Moyen Âge (Florence, 2005), 511-24.

${ }^{6}$ Robert Pasnau considers what he calls the 'subjective-objective ambiguity that infects scholastic discussions' as fundamental to a whole range of medieval epistemological 
discourses which seek to address and accommodate 'the circumstances of everyday life' (as opposed to 'ideal theory') via the language of probabilism: see his 'Medieval Social Epistemology: Scientia for Mere Mortals', Episteme, 7 (2010), 23-41 (pp. 23, 34). For a more extensive treatment in the context of both medieval and post-medieval epistemologies, see Robert Pasnau, After Certainty: A History of Our Epistemic Ideals and Illusions (Oxford, 2017), esp. 21-45 and notes. See also Joël Biard on the two aspects of certitude, ex parte nostra and ex parte objecti: 'Certitudo', in Iňigo Atucha, Dragos Calma, Catherine KönigPralong and Irene Zavattero (eds), Mots médiévaux offerts à Ruedi Imbach, FIDEM-TEMA (Porto, 2011), 153-62 (pp. 159-61).

${ }^{7}$ The question of perception could also lead to sceptical questioning of the role of the senses and the opinions we may form on their basis: for an account of some scholastic defences of reliabilist theories of sensory knowledge responding to such questioning, see Dominik Perler, 'Can we trust our senses? Fourteenth-century debates on sensory illusions', in Denery II, Ghosh and Zeeman (eds), Uncertain Knowledge, 63-90; also Pasnau, After Certainty, 46-69 and notes.

${ }^{8}$ On the concept, status and interrogation of the category of 'experts' (experti / periti) in later medieval Europe, see Frank Rexroth, Expertenweisheit: Die Kritik an den Studierten und die Utopie einer geheilten Gesellschaft im späten Mittelalter (Basel, 2008); id., 'Systemvertrauen und Expertenskepsis. Die Utopie vom maßgeschneiderten Wissen in den Kulturen des 12. bis 16. Jahrhunderts', in Björn Reich, Frank Rexroth and Matthias Roick (eds), Wissen, maßgeschneidert: Experten und Expertenkulturen im Europa der Vormoderne (Munich, 2012), 12-44. On the self-image and self-promotion of academic theologians as experts with an exclusive access to the arcane truths of religion, see Elsa Marmursztejn, L'Autorité des maîtres: scolastique, normes et société au XIII siècle (Paris, 2007); Catherine KönigPralong, Le bon usage de savoirs: scolastique, philosophie et politique culturelle (Paris, 
2011); Ian Wei, Intellectual Culture in Medieval Paris: Theologians and the University, c. 1100 - c. 1330 (Cambridge, 2012), 174-84. For the contested role of 'experts' in the age of the papal Schism, see Rudolf Schüssler, 'Jean Gerson, moral certainty and the Renaissance of ancient Scepticism', Renaissance Studies, 23 (2009), 445-62 (esp. pp. 449-54).

${ }^{9}$ Wyclif's complete sermons, including a set dating from his university-years, are edited as Iohannis Wyclif: Sermones, ed. J. Loserth, 4 vols, Wyclif Society (London, 1887-1890). All references are to this edition (henceforth Sermones) and supplied in the footnotes by volume, page and line number. See Anne Hudson, 'Wyclif's Latin Sermons: Questions of form, date and audience', in her Studies in the Transmission of Wyclif's Writings (Aldershot, 2008), n. VI.

10 'The same is he that shall come after me, who is preferred before me: the latchet of whose shoe I am not worthy to loose.' All biblical quotations in English are from the Douay-Rheims translation.

${ }^{11}$ Note that a standard Wycliffite critique of received modes of exegesis was the alleged propensity to focus on irrelevant biblical detail while ignoring the moral and sentential thrust of scripture; and, in this context, Tobias's dog from the Book of Tobit was as it were a favourite bête noire: for background and discussion, see Alastair Minnis, 'Tobit's Dog and the Dangers of Literalism: William Woodford O. F. M. as Critic of Wycliffite Exegesis', in Michael F. Cusato and Guy Geltner (eds), Defenders and Critics of Franciscan Life: Essays in Honor of John V. Fleming (Leiden, 2009), 41-52.

${ }^{12}$ Sermones, 1. 24/17-20. All translations from the Latin are mine.

13 'This generation is a wicked generation.'

${ }^{14}$ Sermones, 1. 138/1-2; 138/8-21.

${ }^{15}$ See Aurélien Robert, 'L’idée de logique morale aux XIII ${ }^{\mathrm{e}}$ et $\mathrm{XIV}^{\mathrm{e}}$ siècles', Médiévales, 63 (2012), 27-46. 
${ }^{16}$ Compare the widespread devotional convention of 'imagining' extra-biblical details so long as these are within the boundaries of faith, as notably exemplified in The Mirror of the Blessed Life of Jesus Christ, Nicholas Love's widely disseminated English version of the pseudo-Bonaventuran Meditationes vitae Christi, itself a text of pan-European diffusion, where Love posits the category of 'reasonable imagination' in defence of his 'imaginations' of the extra-biblical. For an influential study, see Michelle Karnes, Imagination, Meditation and Cognition in the Middle Ages (Chicago, 2011).

${ }^{17}$ Sermones, 1. 72/26-9.

${ }^{18}$ Sermones, $1.43 / 33-44 / 1$.

${ }^{19}$ Sermones, $1.44 / 34-45 / 2$.

${ }^{20}$ On Wyclif's theorisations, see Zénon Kaluza, "La notion de matière et son évolution dans la doctrine wyclifienne" in Maria-Teresa Fumagalli Beonio Brocchieri and Stefano Simonetta (eds), John Wyclif: Logica, Politica, Teologia (Florence, 2003), 113-151; also see J. A. Robson, Wyclif and the Oxford Schools: the Relation of the 'Summa de Ente' to Scholastic Debates at Oxford in the Later Fourteenth Century (Cambridge, 1961).

${ }^{21}$ On Wyclif's invocation of Augustine as his primary hermeneutic authority following scripture, see Frédéric Goubier, 'Wyclif and the logica Augustini', Medioevo, 36 (2011), 13764.

${ }^{22}$ Sermones, 1. 7/27-30.

23 'Quomodo autem sit ex septem panibus pastus tanti populi cum tanta residuitate narrant multi, ut hii, quod idem panis in numero multipliciter eciam digeritur in ventribus diversorum, hii quod novus panis insensibiliter est creatus, et hii comparante antiquo pane ut originali fermento alia panis materia per miraculum insensibiliter applicatur; et relicta prima via impossibili videtur mihi tercia probabilis, relinquendo noticie prime nature, unde et quomodo nova panis materia exalatur': Sermones, 1. 259/32-260/6. 
${ }^{24}$ Sermones, 1. 307/28-33. Note that Wyclif is here positing a 'hierarchy of proofs': when the testimony of saints results in a situation of isostheny (i.e. equipollence of arguments), one must look to the superior level of scripture or reason to settle the question probabiliter. On the gradus probationis in jurisprudence, see Lévy, La hiérarchie des preuves, 26ff.

${ }^{25}$ On the complexities in and development of Wyclif's thought on the subject of the extent to which the viator may or may not certainly know the identity of those belonging to the congregatio predestinatorum or the true Church as opposed to those spuriously claiming that identity, see Stefano Simonetta, 'John Wyclif between Utopia and Plan', in Sophie Włodek (ed.), Société et église: textes et discussions dans les universités d'Europe centrale pendant le moyen âge tardif (Turnhout, 1995), 65-76. The role of probabilism in Wyclif's theories of predestination merits further investigation; for example, there is some pointed usage of the standard probabilistic lexis in De Ecclesia, ed. Johann Loserth, Wyclif Society (London, 1886), e.g. $131 / 6$.

${ }^{26}$ Sermones, 1. 290/32-6. On the range of meanings and uses of 'evidencia', see Pasnau, After Certainty, Index.

${ }^{27}$ For an illuminating account of the semantic range of and complexities in the notion of 'common sense', see Peter von Moos, 'Le sens commun au moyen âge: sixième sens et sens social. Aspects épistémologiques, ecclésiologiques et eschatologiques', Studi Medievali, 43 (2002), 1-58; reprinted in von Moos, Entre histoire et literature, 525-78. See also G. R. Evans, 'The Commonness of Shared Knowledge', in Getting it Wrong: The Medieval Epistemology of Error (Leiden, 1998), esp. 130-44. For an account of the semantic range of 'common sense' in Wycliffite discourses, see Kantik Ghosh, 'After Wyclif: Philosophy, Polemics and Translation in the English Wycliffite Sermons', in Luigi Campi and Stefano Simonetta (eds), Before and After Wyclif, FIDEM-TEMA (Turnhout, forthcoming). 
${ }^{28}$ Alexander Russell, Conciliarism and Heresy in Fifteenth-Century England: Collective Authority in the Age of the General Councils (Cambridge, 2017), 172; Maclean, Interpretation and Meaning, 93-5.

${ }^{29}$ Andrea Aldo Robiglio, 'Christ as Common Doctor and John Duns Scotus's Place in the History of Hermeneutics', in Philippe Büttgen, Ruedi Imbach, Ulrich Johannes Schneider and Herman J. Selderhuis (eds), Vera Doctrina: Zur Begriffsgeschichte der Lehre von Augustinus bis Descartes (Wiesbaden, 2009), 85-113 (p. 92); on the consensus fidelium, see von Moos, 'Sens commun', 29-33.

${ }^{30}$ Contrast the anti-Wycliffite Thomas Netter of Walden's theoretical attempt to locate (and to justify the location of) consensus in early patristic tradition: see Kantik Ghosh, The Wycliffite Heresy: Authority and the Interpretation of Texts (Cambridge, 2002), 183-93.

31 'And behold a leper came and adored him, saying, "Lord, if thou wilt, thou canst make me clean.",

${ }^{32}$ Sermones, 1. 79/8-10.

33 'For who distinguisheth thee? Or what has thou that thou hast not received? And if thou hast received, why dost thou glory, as if thou hadst not received it?'

${ }^{34}$ Sermones, 1. 285/2-5.

${ }^{35}$ Sermones, 1. 44/2-4.

${ }^{36}$ Sermones, 1. 109/14.

37 '[...] and the spirit of God moved [ferebatur, 'was carried'] over the waters.'

${ }^{38}$ Sermones, 1. 5/1-2.

39 'Sed hic dubitatur communiter quomodo Christus capit predicacionem suorum membrorum': see the entire discussion in Sermones, 1. 261/10-262/28.

${ }^{40}$ Sermones, 1. 336/26-9. 
${ }^{41}$ There is not much evidence of widespread usage of this word in British Medieval Latin: DMLBS s.v. musare, mussitare (v.). Wyclif appears to be importing the word into Latin from its widespread usage in Middle English: MED s.v. musen (v.). There may be some justification in classical usage: Lewis and Short s.v. musso (v.).

42 'A little while, and now you shall not see me; and again a little while, and you shall see me: because I go to the Father.'

${ }^{43}$ Sermones, 1. 181/13-14.

${ }^{44}$ Sermones, 1. 163/18-19.

${ }^{45}$ Sermones, 1. 122/2-7. On the conjectural (and probable) inference of the intentions of others from their actions, see Franklin, Science of Conjecture, 203-4.

46 'generetur in populo suscipio probabilis sine hoc quod musitet de opposito': 1. 60/38-61/1. ${ }^{47}$ See Christophe Grellard, 'Probabilisme et approximation du vrai au XIV siècle', in JeanPhilippe Genet (ed.), Verité et credibilité: construire la verité dans le système de communication de l'Occident (13 $3^{e}-14^{e}$ siècles) (Paris, 2015), 65-79 (pp. 72ff). On the association of suscipio with assent secured by means of rhetorical arguments, see Costantino Marmo, 'Suscipio. A key word to the significance of Aristotle's Rhetoric in thirteenthcentury scholasticism', Cahiers de l'Institut du moyen-âge grec et latin, 60 (1990), 145-98 (pp. 167ff).

${ }^{48}$ Sermones, 1. 172/23-6. On the parallelism between the first principles of 'science' and faith in the work of scholastic thinkers such as William of Auvergne, see Sweeney, 'New Standards for Certainty', 53-5.

${ }^{49}$ Sermones, 1. 239/29-32.

${ }^{50}$ Kantik Ghosh, 'Genre and Method in the Late Sermones of John Wyclif', in Ueli Zahnd (ed.), Language and Method: Historical and Historiographical Reflections on Medieval Thought (Freiburg-im-Breisgau, 2017), 167-82 (p. 177). 
${ }^{51}$ Alessandro Conti clarifies how, for Wyclif, predication is conceived of 'as a real relation holding between metaphysical entities', and the varied taxonomies of predication that he had to propose as a result: 'Wyclif as an Opponent of Ockham: A Case of Realist Reaction to Ockham's Approach to Logic, Metaphysics and Theology', in Christian Rode (ed.), A Companion to Responses to Ockham (Leiden, 2016), 109-39 (esp. pp. 121-5); also see id., 'Wyclif's Logic and Metaphysics', in Ian Christopher Levy (ed.), A Companion to John Wyclif: Late Medieval Theologian (Leiden, 1996), 67-125; id., 'Semantic and Ontological Aspects of Wyclif's Theories of Supposition', Vivarium, 51 (2013), 304-26; Laurent Cesalli, 'Le “pan-propositionalisme” de Jean Wyclif', Vivarium, 43 (2005), 125-55; id., 'Augustine and Wyclif on Truth: An Attempt to Elucidate Wyclif's Notion of logica sacre scripture', Recherches de théologie et philosophie médiévales, 80 (2013), 145-63; Alexander Brungs and Frédéric Goubier, 'On Biblical Logicism: Wyclif, virtus sermonis and Equivocation', Recherches de théologie et philosophie médiévales, 76 (2009), 199-244; Frédéric Goubier, 'Wyclif and the logica Augustini', Medioevo, 36 (2011), 137-64. For a very different and influential reading of Wyclif's view of scriptural signification as deeply traditional, see Ian Christopher Levy, John Wyclif's Theology of the Eucharist in its Medieval Context: Revised and Expanded Edition of Scriptural Logic, Real Presence and the Parameters of Orthodoxy (Milwaukee, 2014), esp. 83-126.

${ }^{52}$ For overviews, see Dominik Perler, Zweifel und Gewissheit: skeptische Debatten im Mittelalter (Frankfurt a. M., 2006); Rudolf Schüssler, Moral im Zweifel, vol. 1: Die scholastiche Theorie des Entscheidens unter moralischer Unsicherheit (Paderborn, 2003). ${ }^{53}$ In his forthcoming book The Appeal of the Academic: Biblical Commentary and Translation in Later Medieval England (Cambridge, 2019). 
${ }^{54}$ See n. 1 above; on Oxford as the most likely location for the production of EWS, see Anne Hudson, 'Five Problems in Wycliffite Texts and a Suggestion', Medium Aevum, 80 (2011), $301-24$.

${ }^{55}$ Hudson and Gradon provide detailed notes on sources in EWS vols 4 and 5; see also Pamela Gradon, 'Relation of the English Cycle to Wyclif's Latin sermons', in EWS 3. xcixcxlviii.

${ }^{56}$ On some of the complexities involved in the transmission of Wyclif's scholastic-homiletic discourse in the English vernacular in EWS, see Ghosh, 'After Wyclif: Philosophy, Polemics and Translation' (n. 27 above).

${ }^{57}$ This usage of men as part of the standard phrasing when rendering probabilist discourses from Latin into English is to be distinguished from the much-studied Lollard phenomenon of using trewe men and variants thereof as a shorthand to indicate an 'in-group' of the elect who believe rightly and suffer persecution: see Anne Hudson, 'A Lollard Sect Vocabulary?', in her Lollards and Their Books (London and Ronceverte, 1985), 165-80; Matti Peikola, Congregation of the Elect: Patterns of Self-fashioning in English Lollard Writings (Turku, 2000), $81 \mathrm{ff}$. See also Peikola's brief but useful discussion of men / some men / many men as an 'ideologically unmarked convention', 239.

${ }^{58}$ See, for example, EWS 2. 184/145-6; 242/54; 273/18; 274/38 etc. For examples of a direct translation of the Latin, retaining the impersonal ('It is seyd comunly'), see 2. 201/29-30; $227 / 34$ etc.

${ }^{59}$ EWS 2. 184/148; 203/85-86 etc.

${ }^{60}$ EWS 2. 184/157; 194/32-33; 202/65; 215/42-3 etc.

${ }^{61}$ EWS 2. 190/114-15; 240/10-11; 311/40-41 etc.

${ }^{62}$ EWS 2. 188/62; 250/79-80; 289/4; 296/20 etc.

${ }^{63}$ EWS 2. 212/158; 215/25-26; 235/63-4; 260/25; 261/61; 271/39 etc. 
${ }^{64}$ EWS 2. 228/53; 302/4; 195/72; 224/98; 225/100; 196/74.

${ }^{65}$ Another potentially relevant context, deserving of further investigation, would be provided by the concept of 'trustworthy men' or viri fidedigni, which, as Ian Forrest has recently demonstrated, played a crucial role in English inquisitorial process and other legal contexts: the fidedigni were 'people who adequately fulfilled the symbolic role of providing reliable and trustworthy testimony'. See Ian Forrest, Trustworthy Men: How Inequality and Faith Made the Medieval Church (Princeton and Oxford, 2018), esp. 95-111 (p. 103).

${ }^{66}$ Sermones, 2. 24/29-25/9.

${ }^{67}$ EWS 2. 221/11-17. For wider medieval literal-historical engagement with Herod's trip to Rome and its aims, see A. B. Kraebel, 'Chaucer's Bibles: Late Medieval Biblicism and Compilational Form', Journal of Medieval and Early Modern Studies, 47 (2017), 437-60 (pp. 448, 458-9, n. 41).

68 'Then was fulfilled that which was spoken by Jeremias the prophet, saying: A voice in Rama was heard, lamentation and great mourning; Rachel bewailing her children'.

${ }^{69}$ For details, see Hudson's notes in EWS 5. 218-9.

${ }^{70}$ EWS 2. 222/3-43.

${ }^{71}$ On the scholastic dubium and its association with ambiguities which are encountered in the course of the lectio of authoritative texts, see Mariken Teeuwen, The Vocabulary of Intellectual Life in the Middle Ages, CIVICIMA (Turnhout, 2003), 322-5.

72 Sermones, 2. 25/35-26/37. Wyclif is here punning on 'presumption' as a legal category: on the various grades of legal praesumptio, see Lévy, Hiérarchie des preuves, 62-6, 83-4; on 'probable presumption', see 109; also Maclean, Interpretation and Meaning, 101-3.

${ }^{73}$ EWS 2. 222/44-223/55.

${ }^{74}$ For a succinct account of this vocabulary, see Schüssler, Moral im Zweifel, 1. 50-63; Evans, Medieval Epistemology of Error, 166-76. For a particular late-medieval exploration of 
the categories of assent, see Christophe Grellard, 'How is it possible to believe falsely? John Buridan, the vetula, and the psychology of error', in Denery II, Ghosh and Zeeman (eds), Uncertain Knowledge, 91-113; also see Pasnau, After Certainty, Index under 'Belief'. ${ }^{75}$ On Wyclif’s and his followers' usage of 'express', see Ghosh, Wycliffite Heresy, passim, and further references therein.

76 'And pis we redon of seynt Thomas, and trowen it betture, but lesse pan feip. And pus schulde we not stryue as folus, how hye pis Thomas is in heuene': EWS 2. 225/108-10. ${ }^{77}$ Craft is a word of complex and wide semantic range in Middle English, encompassing meanings ranging from 'moral strength or virtue' through 'skill' or 'industry / diligence' to 'artifice', 'trickery' etc.: MED s.v. craft (n. (1)).

${ }^{78}$ EWS 2. 223/56-225/122; Hudson's notes are EWS 5. 218-20.

${ }^{79}$ EWS 2. 311/39-312/58.

80 'Conscience', synderesis and their categories and varieties elicited a vast range of scholastic discussion, and could involve a fundamental ambiguity about whether conscience consists in set of deontic beliefs (i.e. our beliefs regarding what we ought to do) as opposed to knowledge: see Timothy C. Potts, 'Conscience', in Norman Kretzmann, Anthony Kenny and Jan Pinborg (eds), The Cambridge History of Later Medieval Philosophy (Cambridge, 1982), 687-704 (pp. 692-3). Also useful for our purposes are Michael G. Baylor, Action and Person: Conscience in Late Scholasticism and the Young Luther (Leiden, 1977), which discusses extensively late-medieval debates around the 'erroneous conscience'; and Peter von Moos, “"Public" et "privé" á la fin du Moyen Âge: le "bien commun” et la "loi de la conscience", Studi medievali, 41 (2000), 505-48; revised version in von Moos, Entre histoire et literature, 471-510. For the twelfth and thirteenth centuries, the foundational work remains Odon Lottin, Psychologie et morale aux XII et XIII siècles, 6 vols in 8 (Louvain, 1942-60), 1 (1948).

${ }^{81}$ EWS 2. 281/35-6. 
${ }^{82}$ On this text, which accompanies the sermon cycle in fourteen manuscripts, and which draws in part on Wyclif's Expositio textus Matthei xxiv, see Hudson's Introduction in EWS 1. 49-50, and her notes in EWS 5. 263-76.

${ }^{83}$ John Wyclif, Opera Minora, ed. Johann Loserth, Wyclif Society (London, 1913), 354-82.

${ }^{84}$ The protestatio praemissa is the conventional scholastic assertion of humility and deference to ecclesiastical authority and correction, in effect a get-out clause safeguarding academic freedom: see Andrew Larsen, The School of Heretics: Academic Condemnation at the University of Oxford, 1277-1409 (Leiden, 2011), 270-72.

${ }^{85}$ Wyclif, Opera Minora, ed. Loserth, 354/7-10.

${ }^{86}$ On the fundamental text-exposition binary in Wycliffite biblical hermeneutics, see Ghosh, Wycliffite Heresy, passim. On the parallel text-commentary binary in jurisprudence and Justinian's 'prohibition' on commentary, see Maclean, Interpretation and Meaning, 50-9. ${ }^{87}$ EWS 2. 328/5-8.

${ }^{88}$ EWS 2. 333/135-7; 335/176-7; 336/210-11; 340/331-2.

${ }^{89}$ EWS 2. 345/465-7.

${ }^{90}$ EWS 2. 346/487, 346/490-92. This is a likely vernacularisation of the scientia-fides-opinio triad, as, for instance, formulated by Hugh of St Victor in De sacramentis: 'Fidem esse certitudinem quamdam animi de rebus absentibus, supra opinionem et infra scientiam constitutam'; for this reference and discussion, see Schüssler, Moral im Zweifel, 1. 51. Wyclif himself draws on Hugh in his epistemological discussions in De Dominio Divino, ed. Reginald Lane Poole, Wyclif Society (London, 1890), 77/18.

${ }^{91}$ EWS 2. 359/856-8.

${ }^{92}$ EWS 2. 364/981-3. On conscience and perplexitas, see Sven Grosse, Heilungsgewißheit und Scrupulositas im späten Mittelalter: Studien zu Johannes Gerson und Gattungen der Frömmigkeitstheologie seiner Zeit (Tübingen, 1994), 13; also Corran, Lying and Perjury, 53- 
4. On medieval castigation of papal law as an 'intolerable burden' or an 'unbearable yoke' designed to ensnare and subjugate, see Bernard J. Verkamp, The Indifferent Mean: Adiaphorism in the English Reformation to 1554 (Athens, OH, 1977), 6-11.

${ }^{93}$ John Mirk's Festial, ed. Susan Powell, 2 vols, EETS 334, 335 (Oxford, 2009-11); A Macaronic Sermon Collection from Late Medieval England: Oxford, MS Bodley 649, ed. Patrick J. Horner (Toronto, 2006).

${ }^{94}$ On prologues, see Alastair Minnis, Medieval Theory of Authorship: Scholastic Literary Attitudes in the Later Middle Ages, $2^{\text {nd }}$ edn (Aldershot, 1988), 40ff; Gilbert Dahan, Lire la Bible au moyen âge: essais d'herméneutique médiévale (Geneva, 2009), 57-84.

${ }^{95}$ For the clear distinction between cognitive and institutional concepts of faith, I am indebted to Christophe Grellard's current work on 'implicit faith' in Wyclif, as presented at a conference on 'Wycliffism and Hussitism: Contexts, Methods, Perspectives', Oxford, 23-25 May 2018.

${ }^{96}$ See Christina von Nolcken, 'A "Certain Sameness” and our response to it in English Wycliffite texts', in Richard G. Newhauser and John A. Alford (eds), Literature and Religion in the Later Middle Ages: Philological Studies in Honour of Siegfried Wenzel (Binghampton, NY, 1995), 190-208; Fiona Somerset, Feeling like Saints: Lollard Writings after Wyclif (Ithaca, 2014).

${ }^{97}$ In The Works of a Lollard Preacher. The Sermon Omnis plantacio, The Tract Fundamentum aliud nemo potest ponere and the Tract De oblacione iugis sacrificii, ed. Anne Hudson, EETS O.S. 317 (Oxford, 2001), 157-256.

${ }^{98}$ I use 'prophetic' in the wider sense as encompassing preaching, exegesis and theological work which have as mission the revelation of divine providence in human history and the elucidation of spiritual meaning in hidden mysteries: see Brian Fitzgerald, Inspiration and 
Authority in the Middle Ages: Prophets and their Critics from Scholasticism to Humanism

(Oxford, 2017). Also see Robert Lerner, 'Ecstatic Dissent', Speculum, 67 (1992), 33-57.

${ }^{99}$ See Ghosh, Wycliffite Heresy, 22-66 (esp. pp. 60-66).

${ }^{100}$ See, for example, Kantik Ghosh, 'Logic and Lollardy', Medium Aevum, 76 (2007), 251-

67.

101 'Jean Gerson, moral certainty’, pp. 457, 461. See also David Zacharian Flanagin, 'Extra ecclesia salus non est - sed quae ecclesia? Ecclesiology and Authority in the Later Middle Ages', and Thomas M. Izbicki, 'The Authority of Peter and Paul: the Use of Biblical Authority during the Great Schism', both in Joëlle Rollo-Koster and Thomas M. Izbicki (eds), A Companion to the Great Western Schism (Leiden, 2009), 333-74, 375-94.

102 There are many references to the Schism scattered across the sermons: e.g. 'For bodyly turment ys now ful greet whan o pope sendip byschopus and monye men to sle monye men, wymmen, and children; and for pe topur pope comen monye azenus hem; and cause of pis fiztyng is a fendus cause, for no man of erpe wot whepur of pese popys be a feend to be dampned in helle, or ellus pei bope.': EWS 2. 91/100-92/105.

${ }^{103}$ EWS 2. 353/693-5.

${ }^{104}$ See Robert N. Swanson, 'Dubius in fide fidelis est? Doubt and Assurance in Late Medieval Catholicism', in Frances Andrews, Charlotte Methuen and Andrew Spicer (eds), Doubting Christianity: The Church and Doubt, SCH 52 (Cambridge, 2016), 186-202. 